\title{
NISAN KUNO DI JAILOLO: BUKTI PERKEMBANGAN ISLAM ABAD KE-18 DI MALUKU UTARA
}

\section{ANCIENT GRAVESTONE IN JAILOLO: EVIDENCE OF THE DEVELOPMENT OF 18th CENTURY ISLAM IN NORTH MOLUCCAS}

\author{
Laila Abdul Jalil \\ Dinas Pendidikan dan Kebudayaan Kota Ternate \\ jalil_laila@yahoo.co.id
}

\begin{abstract}
Moluccas Islands which is rich of spices has become an appeal for the foreign trades to come make a trades of spices. The first foreign traders who visited the Moluccas Island are muslim Arab traders. The entry of Islam into Jaillolo is marked by the existence of ancient gravestone in the Village of Galala and Gam Lamo. This paper aims to describe the process of entry through the variatons of ancient gravestone in Jailolo. This preliminary study used descriptive method of analysis.
\end{abstract}

Keywords: Spices, The Coming of Islam, Moluccas, Ancient Gravestone.

\begin{abstract}
ABSTRAK
Kepulauan Maluku yang kaya akan rempah-rempah telah menjadi daya tarik bagi para pedagang asing untuk datang dan berdagang rempah-rempah. Pedagang asing yang pertama mendatangi Kepulauan Maluku adalah pedagang Arab muslim. Masuknya Islam ke Jailolo ditandai dengan keberadaan nisan-nisan kuno di Desa Galala dan Gam Lamo. Tulisan ini bertujuan untuk mengetahui proses masuknya Islam melalui variasi nisan kuno di Jailolo. Penelitian awal mengenai peninggalan arkeologi Islam di Jailolo ini menggunakan metode deskriptif analisis.
\end{abstract}

Kata kunci: Rempah-Rempah, Kedatangan Islam, Maluku, Nisan Kuno.

Tanggal Masuk $\quad: 16$ Agustus 2017

Tanggal Diterima : 20 Desember 2017 


\section{PENDAHULUAN}

Penelitian dan diskus
mengenai masuk dan berkembangnya Islam di Indonesia masih sangat terbuka luas. Selama ini penelitian mengenai sejarah perkembangan Islam di Indonesia lebih banyak difokuskan di wilayah Indonesia Barat dan hanya sedikit minat peneliti untuk melakukan penelitian di wilayah Indonesia Timur. Ini mungkin disebabkan karena masih minimnya informasi mengenai peninggalan kepurbakalaan Islam di wilayah Indonesia Timur. Dalam tulisan ini penulis tidak menggunakan istilah Maluku Utara namun menggunakan kata Maluku karena Maluku Utara baru terbentuk pada tahun 1999 yang merupakan hasil pemekaran dari Propinsi Maluku berdasarkan Undang-Undang No. 46 Tahun 1999 tanggal 4 Oktober 1999 dan diresmikan pada tanggal 12 Oktober 1999 dengan ibukota di Sofifi.

Sejumlah sarjana Barat terutama Belanda memegang teori bahwa asal muasal Islam di Nusantara adalah dari Anak Benua India, bukannya Persia atau Arabia. Pijnapell mengaitkan asal muasal Islam di Nusantara dengan wilayah Malabar dan Gujarat. Menurutnya, orang-orang Arab bermazhab Syafi'i bermigrasi dan menetap di India, kemudian membawa pengaruhnya ke Nusantara. Teori ini dikembangkan oleh Snouck Hurgronje yang berpendapat bahwa ketika Islam sudah mapan di kota pelabuhan Anak Benua India, muslim Deccan, yang tinggal di sana sebagai pedagang perantara dalam perdagangan Timur Tengah dengan Nusantara datang ke dunia Melayu-
Indonesia sebagai penyebar Islam pertama. Baru kemudian disusul oleh orang Arab, kebanyakan keturunan nabi Muhammad Saw yang ditandai dari pemakaian gelar Sayyid dan Syarif, mereka menyempurnakan penyebaran Islam di Nusantara. (Azra, 1995:24).

Islam di Maluku Utara erat kaitannya dengan pedagang Arab yang datang ke Kepulauan Maluku, yang mereka juluki dengan Jazirah al-Muluk, negeri para raja (Ricklefs: 2008, 45). Menurut penjelasan yang didapat dari pihak keluarga kedaton Ternate, disebut dengan istilah Jazirah al-Muluk karena Kepulauan Maluku terbagi atas 4 kerajaan yakni Jailolo, Bacan, Tidore, dan Ternate. (Ricklefs, 2008:142). Menurut pihak kedaton, Kepulauan Maluku adalah daerah pertama yang disinggahi oleh pedang Arab sehingga mereka berkeyakinan bahwa Islam pertama berkembang di Kepulauan Maluku Utara.

Van Fraassen seperti yang dikutip oleh Adnan Amal dalam bukunya Kepulauan RempahRempah; Perjalanan Sejarah Maluku Utara 1250-1950 mengemukanan, bahwa nama Maluku telah dicatat dalam kitab Nagarakertagama sebagai Maloko yang diadopsi dari pedagang Arab yang datang berniaga ke Kepulauan Maluku. (Amal, 2010: 5)

Walau pun orang Arab yang pertama kali singgah ke Maluku, namun catatan mengenai Kepulauan Maluku pertama kali disebutkan oleh para ahli geografi Tiongkok dalam Sejarah Dinasti Tang (618-906) yang menyebut Kepulauan Maluku dengan Mi-li-kiu dan digunakan untuk menentukan posisi Pulau Bali. Dalam 
catatan Sejarah Dinasti Ming (13681643) menceritakan tentang Maluku yang terletak di Samudera Tenggara dan memiliki reputasi sebagai negara kaya. Pulau itu banyak sekali terdapat dupa (cengkih) yang jika turun hujan dupa akan berjatuhan dan menutupi tanah. Jumlahnya sangat banyak sehingga penduduk tidak dapat mengumpulkannya semua. Pemimpinnya selalu menyimpan cengkih dalam jumlah yang banyak dan dijual kepada kapal-kapal dagang yang mengunjungi Maluku. Orang Tionghoa mengunjungi Maluku untuk membeli cengkih karena cengkih berguna untuk menyembuhkan tidak enak badan. (Groeneveldt, 2009: 166). Perdagangan rempah ini juga yang menjadi pemicu pedagang Arab datang sehingga menghasilkan tinggalan budaya Islam di Maluku.

$$
\text { Data awal mengenai }
$$

peninggalan Islam di wilayah Indonesia Timur ditemukan di daerah Jailolo. Jailolo merupakan bagian dari 4 kesultanan yang ada di Maluku yang lahir karena adanya perjanjian Moti Verbond ${ }^{1}$ yang diprakarsai oleh Sultan Sida Arif Malamo (1322-1331) yang membagi wilayah kekuasaan menjadi empat wilayah (Abdulrahman, 2013: 22) yakni:

1. Ternate/ Alam ma Kolano= penguasa alam yang meliputi Ternate, Sulawesi bagian Timur dan Utara hingga pulau Mindanao

2. Tidore/ Kie ma Kolano= penguasa gunung meliputi Tidore, Halmahera Tengah dan Selatan, Maluku Selatan hingga tanah Papua

3. Jailolo/ Jiko ma Kolano= penguasa teluk meliputi

1 Moti Verbond adalah perjanjian yang mengatur pembagian wilayah di antara 4 wilayah Halmahera Utara dan Barat

4. Bacan/ Dehe ma Kolano= penguasa tanjung meliputi Pulau Bacan dan Pulau Obi. Jailolo masuk dalam wilayah administratif Kabupaten Halmahera Barat merupakan salah satu kerajaan Islam di Maluku Utara pada masa lampau. Dari beberapa informasi yang penulis dapatkan, menyebutkan bahwa Jailolo merupakan kerajaan tertua di Maluku Utara. Sebagai kerajaan tertua tentu tidak mengherankan jika di Jailolo dijumpai peninggalan arkeologis Islam berupa masjid, nisan, benteng, dan fragmen keramik asing dari Cina dan Eropa. Dalam satu kesempatan menjelajah di Jailolo, terutama di desa Galala dan Gam Lamo, saya sempat menemukan persebaran nisan kuno dan fragmen keramik asing yang tersebar di permukaan tanah. Temuan ini menunjukkan adanya indikasi permukiman dan aktifitas perdagangan pada masa lampau.

Nisan-nisan kuno yang ditemukan di Jailolo sejauh ini belum teridentifikasi secara detil. Hal ini dikarenakan kurangnya informasi mengenai keberadaan peninggalan arkeologi Islam di Indonesia bagian timur. Berbeda dengan Aceh di mana nisan-nisan kuno di Aceh sudah banyak ditulis, bahkan Mohd. Yatim dalam karyanya Batu Aceh: Early Islamic Gravestones in Peninsular Malaysia melakukan klasifikasi nisan Aceh ke dalam empat belas tipe dan menjadi rujukan bagi peneliti-peneliti selanjutnya. Temuan nisan kuno di Jailolo dalam penelitian awal ini lebih kepada pencatatan keberadaan dan deskripsi singkat mengenai ornamen yang dijumpai pada nisan.

kesultanan di Kepulauan Maluku (Abdulrahman, 2013: 22) 
Pertanyaan besar mengenai temuan nisan kuno di Jailolo adalah bagaimana variasi nisan kuno di Jailolo?

\section{METODE}

Penelitian awal ini bertujuan untuk mengetahui proses masuknya Islam melalui tipologi nisan kuno yang dijumpai di Jailolo. Penelitian ini menggunakan metode deskriptif analisis dimana nantinya nisan-nisan kuno di Jailolo akan dianalisa berdasarkan bentuk dan ornamen. Pengumpulan data dilakukan melalui teknik survei permukaan dan mengklasifikasikan temuan permukaan berupa nisan-nisan kuno serta fragmen keramik asing. Selain itu, studi pustaka digunakan untuk melengkapi informasi mengenai sejarah masuknya Islam ke Kepulauan Maluku terutama ke Jailolo. Data dari hasil survei kemudian dianalisis dengan membandingkan temuan nisan yang ada di Jailolo dengan nisan-nisan kuno yang ada di Aceh.

\section{HASIL PENELITIAN}

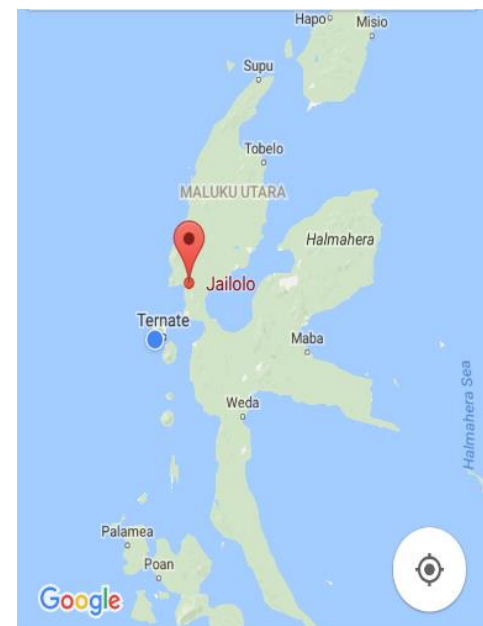

Gambar 1. Letak Jailolo, Ibukota Kabupaten Halmahera Barat

(Sumber: Google Earth)
Pada masa lalu, Jailolo merupakan bagian dari Provinsi Maluku sebagai sebuah kota kabupaten. Maluku yang dikenal sebagai penghasil rempah-rempah (spice islands) banyak dikunjungi oleh pedagang asing. Jauh sebelum kedatangan bangsa Eropa, Kepulauan Maluku banyak disinggahi oleh pedagang Arab. Selain itu, Kepulauan Maluku juga disinggahi oleh pedagang dari daerah Jawa, Melayu, Makassar, Cina, dan Gujarat dengan tujuan untuk berdagang rempah-rempah terutama cengkeh dari Tidore dan Ternate di Maluku Utara serta pala di Pulau Banda, Kabupaten Maluku Tengah.

Pulau Jailolo merupakan wilayah yang berbentuk seperti lengan panjang. Salah satu sisinya berseberangan dengan Ambon dan Seram sedangkan sisi lainnya terbentang hingga ke utara Kepulauan Morotai. Semua penduduknya pada masa lalu menjalankan tradisi Pagan. Pulau ini memiliki banyak makanan dan penduduknya banyak membuat perahu. Sebagian dari penduduknya menjadi bajak laut dan sebagian lainnya menjadi pedagang. Rajanya pengikut Muhammad (Islam). Orangorang yang datang berdagang ke Maluku membawa emas (Pires, 2016: 286).

Tome Pires dalam bukunya
Suma Oriental menceritakan
mengenai Kepulauan Maluku (Maluqo) sebagai penghasil cengkih terdiri dari lima pulau. Ternate sebagai pulau utama dilanjutkan dengan Tidore, Moti (Motes), Makian (Maquem), dan Bacan (Pacham). Cengkih liar tumbuh dalam jumlah yang cukup banyak yang juga ditemukan di pelabuhan Jailolo (Gilolo) yang terletak di Pulau Jailolo (Halmahera, Batochina). Kelima pulau ini menghasilkan sedikitnya 
6.000 bahar cengkih setiap tahun bahkan kadang 1.000 bahar lebih banyak atau sedikit. Satuan bahar yang mereka gunakan berdasarkan pada satuan bahar yang berlaku di Malaka. Cengkih dipanen sebanyak enam kali dalam setahun. Dalam satu kali pelayaran dari Malaka ke Banda dan Maluku melibatkan 8 jung, dan pelayaran ke Gresik menggunkan 3 atau 4 jung (Pires, 2016: 276). Jaringan perdagangan dan jalur pelayaran regional dan internasional di Indonesia bagian timur terutama di Maluku sebagai pusat rempah-rempah selain didapat dari berita yang ditulis oleh Tome Pires juga dari berita Antonio Galvao dalam $A$ Treatise on the Molucas Historia das Moluccas yang ditulis sekitar tahun 1544 yang menceritakan berbagai hasil bumi, jenis burung, adat kebiasaan masyarakat dan raja-raja, pembuatan berbagai jenis kapal, peperangan, dan sebagainya. Termasuk kedatangan bangsa Arab, Persia, Melayu, Tiongkok dalam tujuannya mengambil komoditas perdagangan rempah-rempah terutama cengkih dan pala. Jalur pelayaran tersebut membentuk jaringan perdagangan dengan berbagai negeri di bagian timur Indonesia. Dari Malaka melalui Jawa, Banda, dan Maluku. Juga melalui pesisir selatan Kalimantan dan Sulawesi (Tjandrasasmita, 2009: 41). Gilolo (Jailolo) atau Halmaheira dalam Bahasa Belanda telah mengalami perubahan permukaan bumi. Misalnya kenaikan sebuah gunung berapi dari dasar laut di Gamokonora di semenanjung utara pada tahun 1673. Tanah Jailolo adalah tanah vulkanis dan di pantai ada gugusan karang. Ciri-ciri dan sifat permukaan bumi di Jailolo membuktikan bahwa daratan ini sudah tua yang dibuktikan berdasarkan beberapa jenis hewan khas Jailolo. Pada masa lampau Jailolo (Gilolo) merupakan tempat tinggal para Sultan Ternate. Kemudian Belanda meminta para sultan Ternate pindah ke tempat yang mereka tempati sekarang (Kedaton Ternate) (Wallace, 2009: 237).

Kedatangan pedagang muslim Arab ke Maluku memberi dampak terhadap pertukaran agama masyarakat lokal. Menurut tradisi setempat, agama Islam telah datang ke Maluku sejak abad ke-14, sedangkan di Aceh pada abad ke-13 sudah ada kerajaan Islam yaitu Samudera Pasai yang dipimpin oleh Sultan Malik al- Saleh. Raja Ternate yang kedua belas, Molomateya (1330-1357) bersahabat karib dengan orang Arab yang memberi petunjuk cara-cara pembuatan kapal, namun sepertinya belum sampai pada tahap pengenalan agama Islam (Daliman, 2012: 210).

Bukti bahwa pedagang Arab sudah lebih awal bermukim di Kepulauan Maluku salah satunya dapat dilihat di Pulau Ternate, terdapat permukiman orang Arab yang mendiami Kampung Muhajirin.

Selain orang Arab, proses Islamisasi juga ditandai degan adanya kunjungan Sultan Ternate (Zainal Abidin) ke Gresik. Hubungan Jawa dengan Maluku memperlancar proses Islamisasi di Kepulauan Maluku. Jailolo merupakan kerajaan Islam tertua di Maluku yang berdiri pada tahun 1321 yang meliputi sebagian Halmahera dan pesisir Pulau Seram. Namun dalam perkembangan Islam di Kepulauan Maluku, Ternate, Tidore, dan Bacan jauh lebih pesat. Hal ini karena jumlah penduduk di ketiga pulau tersebut jauh lebih banyak.

Masuknya pengaruh Islam ke Kepulauan Maluku menyisakan data- 
data arkeologis berupa nisan-nisan kuno terutama di Jailolo yang tersebar di enam titik yang tersebar di Desa Galala, Desa Gam Ici, dan Desa Gam Lamo, Jailolo. Berdasarkan tipologi, nisan kuno di Jailolo berbentuk pipih dan balok. Ornamen pada nisan berupa kaligrafi dan flora berbentuk bunga serta suluran. Kaligrafi yang sudah berhasil terbaca adalah ayat Kursi yang dijumpai pada nisan di Desa Gam Lamo. Beberapa nisan lainnya dijumpai kaligrafi namun belum berhasil terbaca. Bentuk-bentuk nisan tersebut adalah:

\section{Nisan Kuno I, Desa Gam Lamo}

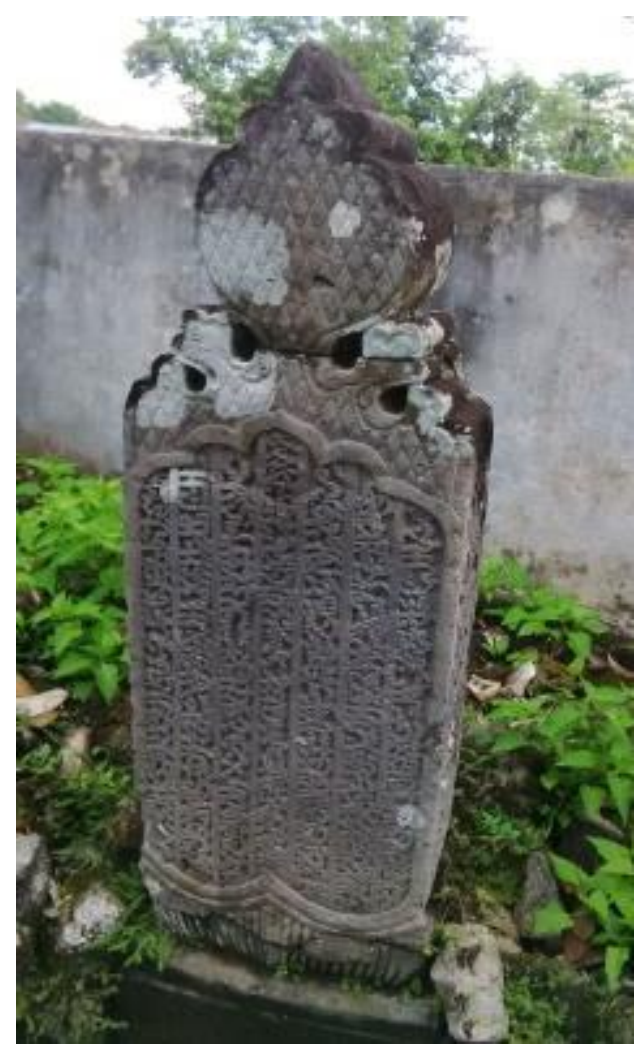

Gambar 2. Nisan Gam Lamo 1

(Sumber: Dokumen Pribadi, 2016)

Nisan kuno di titik pertama berada di Desa Gam Lamo, Kabupaten Jailolo. Nisan kuno di Jailolo seperti halnya nisan kuno masa Islam yang ditemukan di daerah lain juga memiliki kaligrafi. Salah satu nisan kuno ditemukan di desa Gam Lamo (Nisan Gam Lamo 1). Nisan ini memiliki ukuran tinggi $160 \mathrm{~cm}$ dan lebar $80 \mathrm{~cm}$. Berbentuk pipih dengan bagian kepala nisan berbentuk seperti buah delima.

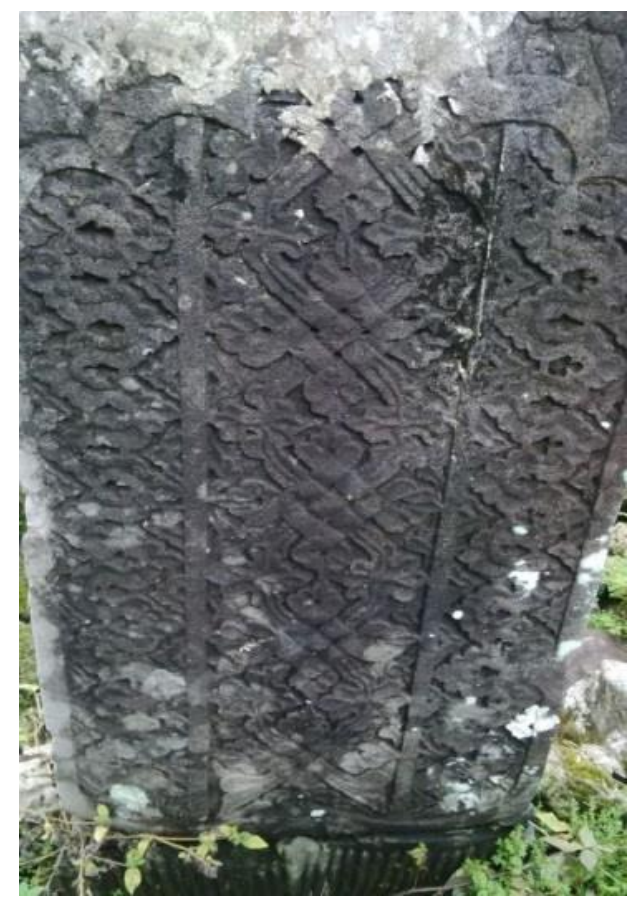

Gambar 3. Ornamen pada Badan Nisan Gam Lamo 1 Sisi Samping

(Sumber: Dokumen Pribadi, 2016)

Bagian badan nisan sisi dalam dihiasi dengan kaligrafi yang berisi ayat Kursi. Bagian badan nisan sisi luar dihiasi dengan motif flora yang pada sisi kiri dan kanan badan nisan terdapat motif geometris dan flora (panah kuning). Sepintas bentuk flora pada sisi samping badan nisan terlihat seperti bentuk anyaman dengan motif bunga.

Nisan bagian kaki kondisinya dalam keadaan sudah rusak karena patah dan bagian puncak nisan telah hilang. Ornamen pada bagian kaki nisan juga berbentuk flora dan bagian paling bawah berbentuk garis-garis geometris. Bagian dasar kaki nisan berbentuk persegi empat dan 
merupakan bagian yang ditanam ke dalam tanah.
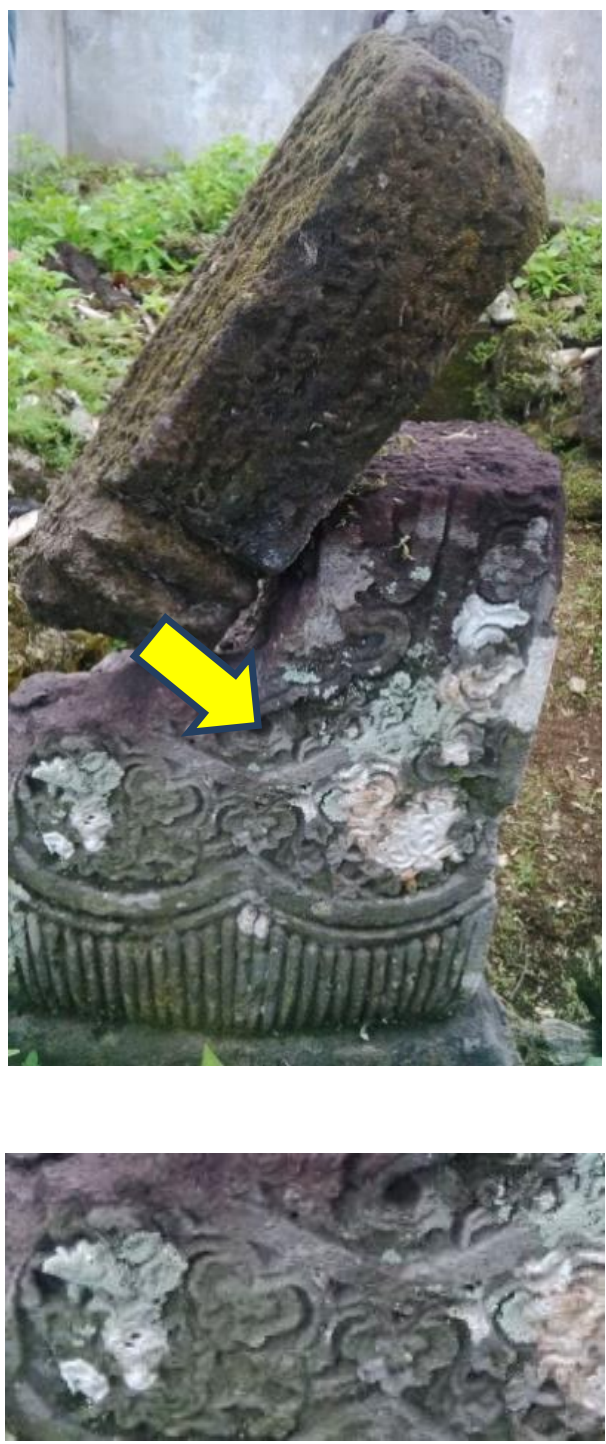

Gambar 4. Bagian Kaki Nisan Gam Lamo 1 yang Sudah Patah (kiri), Detail Motif flora (kanan)

(Sumber: Dokumen Pribadi, 2016)

Selain rusak dan patah, bagian badan dan kaki nisan juga ditumbuhi lumut putih (lycheen) yang lambat laun akan merusak permukaan nisan.

\section{Nisan kuno II, Desa Gam Lamo}

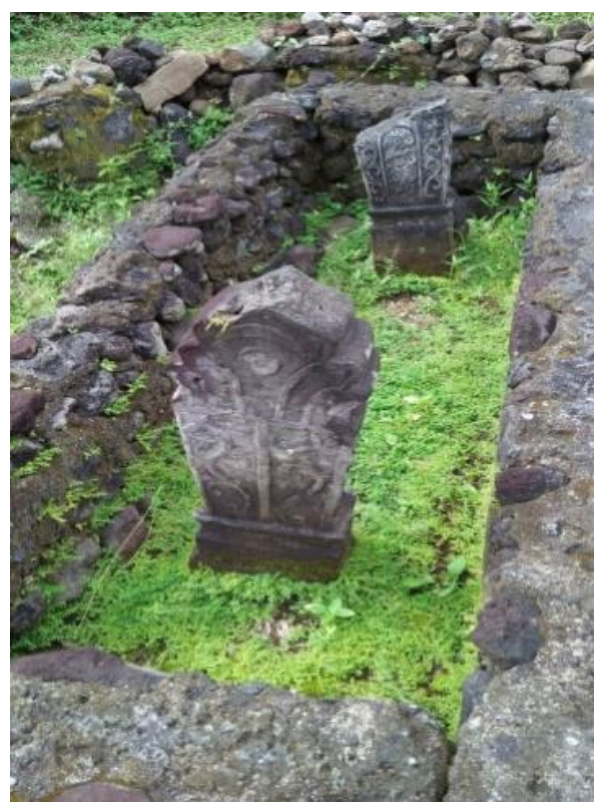

Gambar 5. Bagian Kaki Nisan Gam Lamo 2 yang Sudah Patah.

(Sumber: Dokumen Pribadi, 2016)

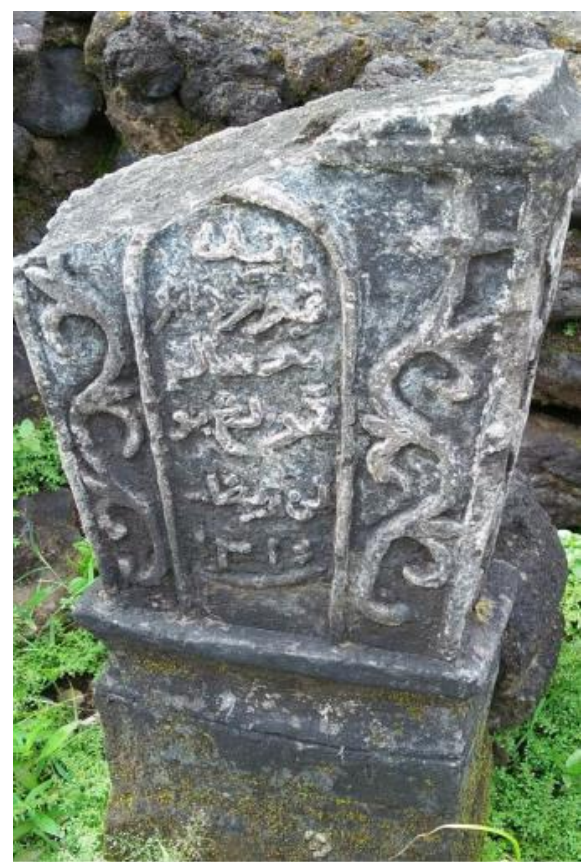

Gambar 6. Detail kaligrafi pada bagian kaki (Sumber: Dokumen Pribadi, 2016)

Inskripsi yang terdapat pada bagian kaki yang berbunyi: inilah kubur Daeng Muda (Mad) telah 
pulang bulan Ramadhan Sanah $1214 .^{2}$

Berlokasi di dekat masjid sultan yang pertama di Desa Gam Lamo. Nisan berbentuk pipih dengan sedikit penataan pada bagian bahu nisan dan bagian puncak nisan dibuat meruncing. Kondisi nisan di dekat masjid kedaton tidak terawat dan seperti terlupakan. Beberapa nisan dalam kondisi berantakan. Hanya yang di bagian dalam pagar nisan yang terbuat dari susunan batu dan semen saja masih terlihat sedikit terawat. Ornamen yang dijumpai antara lain kaligrafi serta pola geometris bentuk lingkaran bulat dan

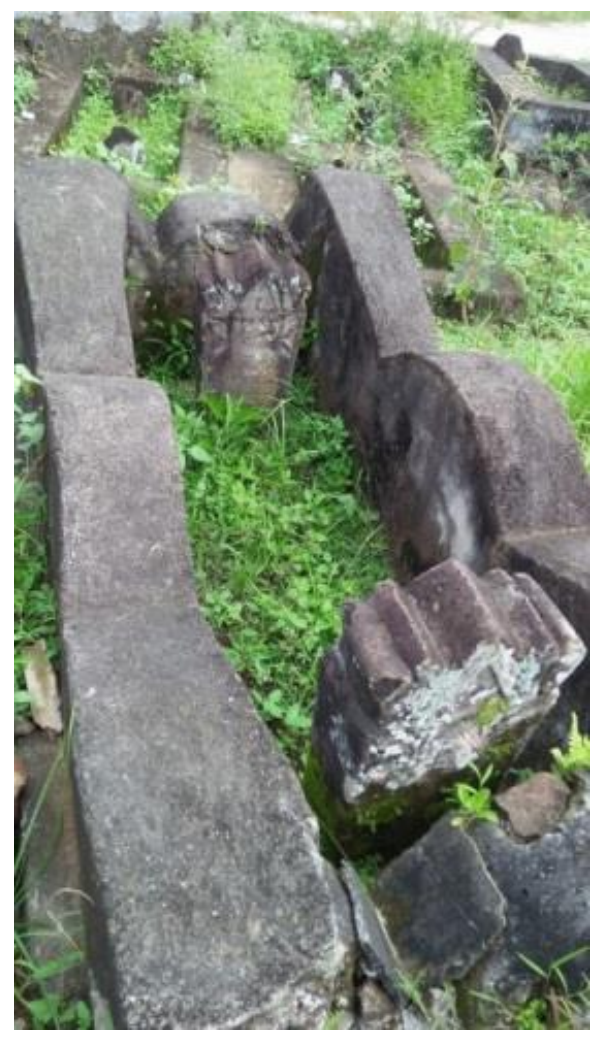

Gambar 7. Bagian Kaki Nisan Gam Lamo 2 yang Sudah Patah

(Sumber: Dokumen Pribadi, 2016)

${ }^{2}$ Hasil yang dibaca oleh Masykur Syafruddin, alumni UIN Ar-Raniry Banda Aceh. di bagian dalamnya diisi dengan motif kelopak bunga berjumlah enam. Pada bagian bawah bidang bulat terdapat dua bentuk lengkung seperti bulan sabit dan sedikit motif flora berbentuk sulur tanaman. Selain ornamen flora, ornamen geometris sederhana mendominasi nisan-nisan kuno di Jailolo.

Tidak dijumpai kaligrafi pada temuan nisan titik kedua ini namun pada bagian badan nisan sisi dalam dan luar terdapat motif berbentuk flora yang diukir seperti bunga merambat. Pada titik kedua ditemukan delapan buah nisan kuno dan kondisinya tidak terawat.

\section{Nisan kuno di Desa Galala}

Berlokasi di Desa Galala, Kabupaten Jailolo. Nisan kuno Galala 1 yang dijumpai di titik ketiga berada

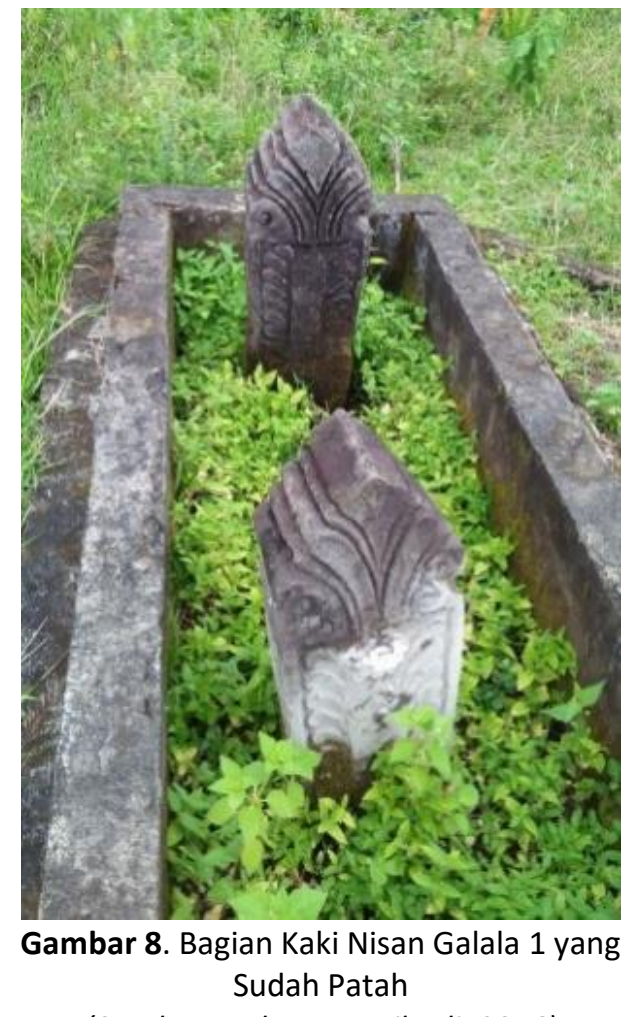

(Sumber: Dokumen Pribadi, 2016) 
dalam pagar yang terbuat dari susunan batu dan oleh masyarakat nisan-nisan ini dianggap sebagai makam keramat yang kerap diziarahi pada waktu-waktu tertentu.

Selain temuan nisan kuno, di Desa Galala banyak dijumpai temuan permukaan berupa fragmen keramik asing terutama Eropa.
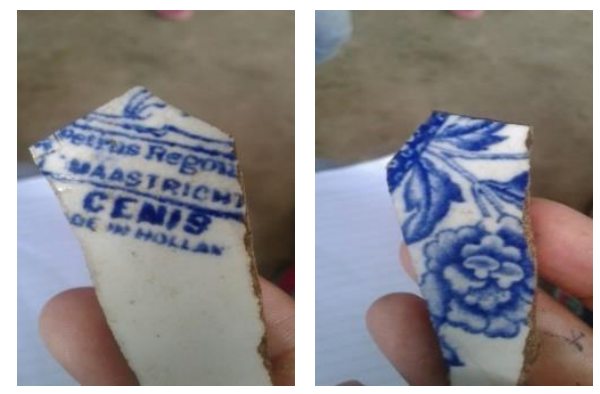

Gambar 9. Keramik Asing Buatan Maastricht (Belanda)

(Sumber: Dokumen Pribadi, 2016)

\section{PEMBAHASAN}

Pada masa lampau Jailolo
berperan dalam perdagangan rempah-rempah terutama cengkih. Berkembangnya Kepulauan Maluku sebagai daerah perdagangan tidak terlepas dari jalur pelayaran di Asia Tenggara yang menghubungkan negeri Cina dengan negeri-negeri "di atas angin", yakni sub-kontinen India, Persia, dan negeri-negeri Arab di Timur Tengah yang berlanjut ke Eropa. Sejak zaman purba, jalur ini telah digunakan oleh para pedagang yang menghubungkan negeri-negeri barat dan timur yang dikenal dengan nama "Jalur sutera" (silk route) yang digunakan oleh kafilah melintasi padang rumput dan gurun pasir serta samudera. Jalur laut semakin penting ketika jalur darat tidak lagi aman karena adanya peperangan di kawasan Asia Tengah. Komoditi yang diperdagangkan di "Jalur sutera" (silk route) selain sutera adalah rempah-rempah yang berasal dari kawasan Asia Tenggara yang menjadi pemasok utama rempahrempah berupa lada, pala, cengkih, dan kayu-kayu yang wangi (Ambary, 1998: 149).

Berita awal mengenai hubungan Timur Tengah dengan Nusantara diperoleh dari sumbersumber Cina dan Arab. Sejarawan Arab seperti Al-Ya'qubi, Abu Zayd, dan Al-Mas'udi menulis tentang Nusantara namun kandungannya lebih kepada cerita-cerita pelayar Arab mengenai hal-hal aneh dan mistis. Pengembara Arab yang datang kemudian seperti lbnu Battutah mendeskripsikan Nusantara secara akurat dan otentik (Azyumardi, 1995: 37).

Kitab Nagarakertagama yang ditulis pada pertengahan abad ke-14 menyebutkan nama-nama tempat yang dapat ditelusuri kembali di pulau-pulau sebelah timur yang pada masa lalu dikunjungi oleh pedagangpedagang dari kerajaan Hindu-Jawa dan kerajaan sebelumnya. Keberadaan orang-orang asing di Kepulauan Maluku juga dapat dilacak dari legenda Soya dan Lutong di Ambon serta nama keluarga seperti Latu-Halat, Raja Barat, Maspaitela (keluarga besar dari Majapahit), Telaga Kodok (nama permukiman pertama orang Jawa), nama tempat Luhu (dari Luwu Sulawesi) (Daliman, 2012: 208).

Bukti tentang kehadiran bangsa Arab ke Maluku disebutkan oleh Tome Pires dalam karyanya Suma Oriental menyatakan bahwa Islam telah masuk ke Maluku sekitar tahun 1459-1460. Berita Portugis menyebutkan jika Islam telah hadir di Maluku pada tahun 1486 saat wafatnya Kaicil Marhum dan digantikan oleh Zainal Abidin. De Clerq menyebutkan bahwa pada awal abad ke-14 masa pemerintahan Sida Arif Malamo di Ternate (1322- 
1331) dan Kaicil Sele di Tidore serta Sida Hasan di Bacan, telah banyak orang Jawa, Cina, Arab, serta Melayu bermukim di Ternate, Bacan, dan Tidore. (Amal, 2010: 238).

$$
\text { Bangsa Arab sebagai }
$$

pendatang pertama ke Kepulauan Maluku untuk berdagang rempahrempah menjadi pembuka jalan bagi bangsa asing lainnya untuk menguasai pusat rempah-rempah yang pada masanya menjadi komoditi perdagangan unggulan. Kedatangan bangsa Arab ke Kepulauan Maluku menyebabkan terjadinya proses konversi agama masyarakat lokal ke Islam.

Tidak dapat dipungkiri bahwa Selat Malaka juga memiliki peranan besar terhadap masuk dan berkembangnya Islam di Nusantara khusunya ke Kepulauan Maluku. Selat Malaka memainkan peran penting dalam posisi strategis sebagai pintu masuk jalur perdagangan internasional pada masanya. Melalui Selat Malaka, pedagang-pedagang dari Arab, Cina, dan terakhir Eropa menjelajah Nusantara dalam rangka mencari sumber rempah-rempah. Peran Sunan Giri sangat penting dalam proses Islamisasi di Maluku. Sultan Zainal Abidin terkenal sebagai Raja Bulawa, Raja Cengkih karena membawa bulawa (cengkih) ke Giri ketika menuntut agama Islam. Sekembali dari Jawa, ia membawa serta seorang mubaligh yang bergelar Tunubahul dan mengembangkan Islam di Maluku. Berita Portugis juga mengungkapkan hubungan antara Jawa dengan Maluku. Menurut Tome Pires, Rajaraja Maluku mulai masuk Islam sekitar tahun 1460-1545. Dikatakan pula bahwa Raja di Maluku menggunakan gelar sultan, sedangkan lainnya hanya menggunakan gelar raja. Masyarakat muslim juga dijumpai di Banda, Hitu, Makyan, dan Bacan (Daliman, 2012: 211).

Masuknya Islam ke Jailolo tidak terlepas dari adanya hubungan Jawa dengan Maluku pada masa lampau dan ditambah lagi dengan peranan Sultan Zainal Abidin salah seorang Sultan Ternate yang belajar Islam ke Giri dan melanjutkan dakwahnya di Kepulauan Maluku. Selain itu, peranan Selat Malaka sebagai pintu gerbang masuknya pedagang-pedagang asing ke Nusantara menyebabkan terjadinya kontak bangsa Arab dengan penduduk Nusantara terutama ke wilayah Indonesia Timur.

Adanya Hubungan Jawa dengan Maluku mendorong berkembangnya pertumbuhan masyarakat muslim khususnya di Jailolo. Pertumbuhan masyarakat muslim pada akhirnya mendorong berkembangnya budaya materi sebagai penanda komunitas muslim dalam hal ini nisan yang memiliki fungsi sakral.

Nisan bukan hanya sebagai penanda kubur, namun juga sebagai penanda status sosial tokoh yang dimakamkan. Dari beberapa temuan nisan kuno di Jailolo diduga bahwa tokoh yang dimakamkan memiliki kedudukan dan peran penting pada masanya.

Berdasarkan pengamatan awal terhadap tinggalan arkeologis Islam di Jailolo diketahui bahwa variasi nisan-nisan kuno di Jailolo terdiri dari bentuk pipih dengan penataan puncak nisan berbentuk buah delima, variasi pipih dengan pahatan pada bagian puncak nisan, variasi pipih dengan puncak nisan polos tanpa pahatan. Berdasarkan variasi nisan dapat disimpulkan bahwa tradisi memahat batu nisan di Jailolo sudah berkembang pesat pada masanya. Kemahiran ini 
mungkin saja didapat dari persentuhan dengan pedagangpedagang asing yang singgah ke Jailolo.

Selain nisan, temuan permukaan yang cukup padat berupa fragmen keramik asing yang tersebar di ketiga desa tersebut mengindikasikan adanya kontak penduduk setempat dengan bangsa asing. Berdasarkan temuan fragmen keramik asing ini mengindikasikan adanya perdagangan yang pesat secara langsung atau tidak langsung antara penduduk setempat dengan bangsa Cina dan Eropa pada masa lampau di Jailolo.

Inskripsi pada nisan di titik kedua yang menyebutkan kata Daeng Muda menunjukkan bahwa yang dimakamkan di lokasi tersebut adalah seorang bangsawan dari Bugis. Tentunya ini menjadi temuan yang menarik dan membuktikan bahwa pada masa lampau Kepulauan Maluku sudah banyak disinggahi oleh para pendatang baik lokal maupun asing. Berdasarkan inskripsi yang dijumpai pada nisan di titik kedua diduga bahwa pengaruh Islam di Kepulauan Maluku terutama di Jailolo juga dibawa oleh orang Bugis yang ikut mengambil peran dalam perdagangan rempah saat itu dan ikut berperan sebagai penyebar Islam.

Seperti umumnya nisan-nisan kuno yang dijumpai di daerah lain, nisan kuno di Jailolo juga menggunakan ornamen kaligrafi dan geometris. Penggunaan ornamen geometris merupakan hal yang lumrah dalam seni Islam. Hal ini dikarenakan adanya larangan penggambaran makhluk hidup, ornamen berbentuk flora dan geometris merupakan ekspresi seniman terhadap lingkungan alam setempat. Selain motif geometris, bentuk flora/buah seperti buah delima merepresentasikan buahbuahan di surga di mana salah satu buah yang disebutkan di dalam alqur'an surah Ar-Rahman ayat 68 adalah buah delima sebagai makanan bagi penghuni surga (Jalil, 2015: 283).

\section{KESIMPULAN}

Salah satu teori mengenai proses masuk dan berkembangnya Islam di Nusantara menyebutkan tentang peranan pedagang Arab sebagai pembawa Islam. Teori ini dapat dibuktikan dari peninggalan nisan kuno di Jailolo. Masuk dan berkembangnya Islam di Jailolo tidak terlepas dari peranan pedagang Arab yang datang ke Kepulauan Maluku pada masa lampau dalam rangka mencari rempah-rempah. Selain membawa pengaruh Islam, kedatangan pedagang Arab ke Kepulauan Maluku menjadi pembuka jalan bagi pedagangan asing lainnya yakni Cina dan Eropa.

Dari sumber-sumber berita asing diketahui bahwa Islam mulai masuk ke Maluku pada abad ke-14. Hubungan Kepulauan Maluku dengan Jawa pada masa lampau terutama Kesultanan Ternate masa pemerintahan sultan Zainal Abidin yang mendalami Islam ke Giri turut memberi andil bagi perkembangan Islam di Kepulauan Maluku. Inskripsi yang terdapat pada salah satu nisan kuno di Jailolo mengindikasikan adanya peranan bangsawan Bugis dalam proses penyebaran Islam pada masa selanjutnya. Angka tahun $1214 \mathrm{H}$ jika dikonversi ke tahun masehi akan diperoleh angka $1794 \mathrm{M}$ (abad ke18). Berdasarkan angka tahun ini dapat disimpulkan bahwa pada abad ke-18 bangsawan yang berasal dari Bugis memiliki peran besar dan 
kedudukan penting yang ditandai dari pemakaian batu nisan berukir.

Berdasarkan hasil penelitian yang dilakukan, diketahui bahwa nisan-nisan kuno berbentuk pipih. Ornamen yang umum digunakan adalah kaligrafi, sulur-suluran, dan bentuk geometris dengan penataan pada bagian bahu dan kepala nisan. Kaligrafi yang ada pada nisan berisi inskripsi ayat Kursi. Jika dibandingkan dengan nisan-nisan yang ada di Aceh, bentuk nisan pipih seperti yang ada di Jailolo berasal dari abad ke-18. Hal ini sejalan dengan temuan nisan di Desa Galala dan Gam Lamo.

\section{SARAN}

Nisan-nisan kuno yang dijumpai di Jailolo merupakan data arkeologis yang memiliki nilai penting dan harus dilestarikan keberadaannya. Tujuannya agar sejarah dan perkembangan Islam di Jailolo semakin terungkap terutama aspek-aspek perdagangan, ekonomi, sosial masyarakat, serta perkembangan Islam di Jailolo pada masa lampau. Pemasangan cungkup sangat dibutuhkan guna melindungi nisan-nisan terutama yang mengandung inskripsi agar informasi penting menyangkut aspek perkembangan Islam di Jailolo tidak hilang akibat faktor cuaca dan iklim.

Sudah saatnya penelitian Islam di Kepulauan Maluku Utara digiatkan guna mengungkap lebih banyak lagi aspek-aspek arkeologi Islam di Nusantara. Penelitian arkeologi Islam di wilayah Indonesia bagian timur masih terbuka lebar mengingat selama ini perhatian peneliti terutama di bidang arkeologi Islam belum terfokus ke wilayah timur. Potensi data peninggalan arkeologi Islam yang cukup besar terutama di wilayah Jailolo diharapkan ke depannya akan mampu mengungkapkan lebih banyak lagi aspek mengenai sejarah masuk dan berkembangnya Islam di wilayah timur Indonesia. Tentunya dibutuhkan penelitian lebih lanjut dan komprehensif dengan melibatkan berbagai pihak antara lain Balai Arkeologi Ambon serta Balai Pelestarian Cagar Budaya Ternate.

\section{UCAPAN TERIMA KASIH}

Dalam kesempatan ini, penulis ingin mengucapkan terima kasih sebesar-besarnya kepada Muslim Arsad yang telah berkenan mengantarkan penulis ke situs-situs peninggalan Islam yang tersebar di Jailolo. Ucapan terima kasih juga penulis sampaikan kepada Ketua Jurusan dan mahasiswa Fakultas Ushuluddin, Adab, dan Dakwah IAIN Ternate yang telah memberikan informasi mengenai keberadaan peninggalan masa Islam di Jailolo.

Ucapan terima kasih juga penulis sampaikan kepada Cheviano E. Alputila, S.Hum yang telah banyak membantu penulis terutama dalam hal teknik penulisan dan sumbangan pemikiran untuk kesempurnaan penelitian ini.

Ucapan terima kasih dan penghargaan setinggi-tingginya juga penulis sampaikan kepada Masykur Syafruddin, alumni UIN Ar-Raniry Banda Aceh yang sering membantu penulis untuk membacakan inskripsi pada nisan-nisan kuno yang penulis jumpai. 


\section{DAFTAR PUSTAKA}

Jalil, Laila Abdul. 2015. Masjid-Masjid Kuno di Aceh. Banda Aceh: Balai Pelestarian Cagar Budaya Aceh dan Sumatera Utara.

Abdulrahman, Jusuf. 2013. Kapita Selekta: Sejarah, Bahasa dan Budaya Moloku Kie Raha. Yogyakarta: Kanisius.

Amal, Adnan. 2010. Kepulauan Rempah-Rempah; Perjalanan Sejarah Maluku Utara, Jakarta: Kepustakaan Populer Gramedia.

Ambary, Hasan Muarif. 1998. Menemukan Peradaban: Jejak Arkeologis dan Historis Islam Indonesia, Jakarta: Logos.

Azra, Azyumardi. 1995. Jaringan Ulama: Timur Tengah dan Kepulauan Nusantara Abad XVII dan XVIII, Jakarta: Mizan.

Daliman. 2012. Islamisasi Dan Perkembangan Kerajaan-Kerajaan Islam di Indonesia. Yogyakarta: Ombak.

Groenevedt, W.P. 2009. Nusantara Dalam Catatan Tionghoa. Jakarta: Komunitas Bambu.

Pires, Tome. 2016 . Suma Oriental. Yogyakarta: Ombak

Ricklefs, M.C. 2008, Sejarah Indonesia Modern 1200-2008. Jakarta: Serambi

Tjandrasasmita, Uka. 2009. Arkeologi Islam Nusantara. Jakarta: Kepustakaan Populer Gramedia.

Wallace, Alfred Russel. 2009. Kepulauan Nusantara: Sebuah Kisah Perjalanan, Kajian Manusia dan Alam, Jakarta: Komunitas Bambu. 